\title{
都市火災伝搬における火の粉飛散の数值解析 \\ NUMERICAL ANALYSIS OF SCATTER OF FIRE BRAND WITHIN URBAN FIRE SPREAD
}

\author{
白石靖 幸*，加藤 信介**，吉田伸治***，村上周三** \\ Yasuyuki SHIRAISHI, Shinsuke KATO, Shinji YOSHIDA \\ and Shuzo MURAKAMI
}

\begin{abstract}
The main driving forces for the propagation of urban fires are the thermal radiation from the fire and the leaping flames due to the drifting firebrands. In the present work, drifting firebrands in an urban fire are numerically simulated by means of CFD with a turbulence model. Firebrands are treated as airborne particles subject to sedimentation due to the gravity. Characteristics of brand drifting are investigated under various wind conditions, sedimentation speed and locations of a brand source. 1) When the approaching flow is relatively slow, the vertical thermal plume is raised by the fire and reaches up to around $100 \mathrm{~m}$ height. In comparison, when the approaching flow is fast, the incoming flow acts to suppress the thermal plume. 2) The sedimentation fluxes over the downstream building roofs increase under high wind conditions, so the risk of the fire spreading increases on the leeward side of the fire. 3) Drifting patterns measured with the sedimentation fluxes over the downstream building roofs and so on, depend much on the effective diameter of brands. 4) When the upward plane of the building catches fire, the circulation flow in front of the burning surface suppresses thermal diffusion in the horizontal direction. In contrast, when the leeward plane of the building catches fire, the leeward circulation behind the building promotes horizontal thermal diffusion. The latter flow results in the reduction in the velocity of thermal plume. 5) When the roof or the leeward plane of the building catches fire, it developed into hot ascending flow patterns which promote the drifting of the firebrand.
\end{abstract}

Keywords : urban fire, drifting firebrands, CFD (Computational Fluid Dynamics) 都市火災、火の粉飛散、数值流体解析

1. 序

火の粉飛散(飛び火)現象 ${ }^{(21)}$ は、火炎からの熱放射とともに都市火 災抁大に影響を及ほす重要な要素となる。多くの都市火災伝搬予測 に関する研究が行われているが、それらは火災の伝搬過程や延焼速 度を過去の被災記録からの統計解析に基づいた延焼モデルによりマ ク口的に予測するものや文1)-5)、3次元的な火炎気流の温度性状を簡 略化した物理モデルと次元解析により予測するというものである文 6),7)。従って、それらは火災の拡大に大きな影響を持つ火炎域の風性 状等の実際の物理現象を解析して予測するというものではない。筆 者らは既往の研究において CFD を用いて都市のミクロな風の流れ を実際に解析し、都市の気流分布、温度分布等から都市火災伝搬シ ミュレーションを行ってきた文8), 9)。

本報では、都市火災の伝搬要团の一つである火の粉飛散による飛 び火現象の物理モデル这2)を作成し、建物周辺の風の流れを再現する CFD解析と火の粉飛散を連成させて都市火级伝搬を解析しょうとす るものである。本来、火の粉の形状は多様であり、また延焼能力の 大きい火の粉は寸法·重量ともに相当に大きいと考えられる。このよ うな場合、正確な予測を行うためには飛散する火の粉に対して働く 重力、抗力、揚力を考虑し、個々の火の粉の輸送をその運動方程式 を解いて、解析することが望ましいと考えられる。本研究では、こ うした検討の第 1 段階として、比較的小粒径 $(1 \mathrm{~mm}$ から $5 \mathrm{~mm}$ の径)
の火の粉に着目し、これらの火の粉を重力沈降する通常の気中浮遊 微粒子としてモデル化し文 ${ }^{10)}$ 、その風による移流・抎散性状を CFD を用いて検討する。今回の CFD 解析と実際の都市火㷋における火の 粉飛散による飛び火現象との対态は、今回検討対象とする比較的小 粒径の火の粉が実際の飛び火現象の中で、どの程度発生し火災の延 狫にどの程度影響を与えるか等の火の粉の発生及び飛散現象のモ デリング、並びに火の粉の発生位置、火源のモデリング等の様々な モデリングの実現象との対态による。また、火の粉が飛散した後に 離れた場所に沈着し、火災が起きるという現象を数值シミュレーシ ヨンにより再現しようとした場合、火の粉が飛散した後に沈着する までに火の粉がどの程度の温度低下を伴うかを解明する必要もある。 これらのモデリングや検討は実現象の詳細な観測 等から行われる ものと考えられるが、本報はその検討を行うものではない。今後の 重要な検討課題であると認識している。尚、本報で採用した火の粉 の飛散モデルは、室内の浮力流れ場における浮遊微粒子の移流・拻散 現象の解析において、解析対象、用いた乱流モデル等の差異はある が、詳細にその予測精度を検証している文10)。

\section{2. 解析概要}

街区スケールでの火炎を想定し、流れ場、温度場の CFD 解析及び 火の粉の払散シミュレーションを連成させて解析を行う。

\footnotetext{
* 東京大学生産技術研究所 助手・工修

** 東京大学生産技術研究所 教授. 工博

*** 東京大学生産技術研究所 博士研究員.工博

Research Assoc., Institute of Industrial Science, Univ. of Tokyo, M. Eng.

Prof., Institute of Industrial Science, Univ. of Tokyo, Dr. Eng.

Postdoctoral Research Fellow, Institute of Industrial Science, Univ. of Tokyo, Dr. Eng.
} 


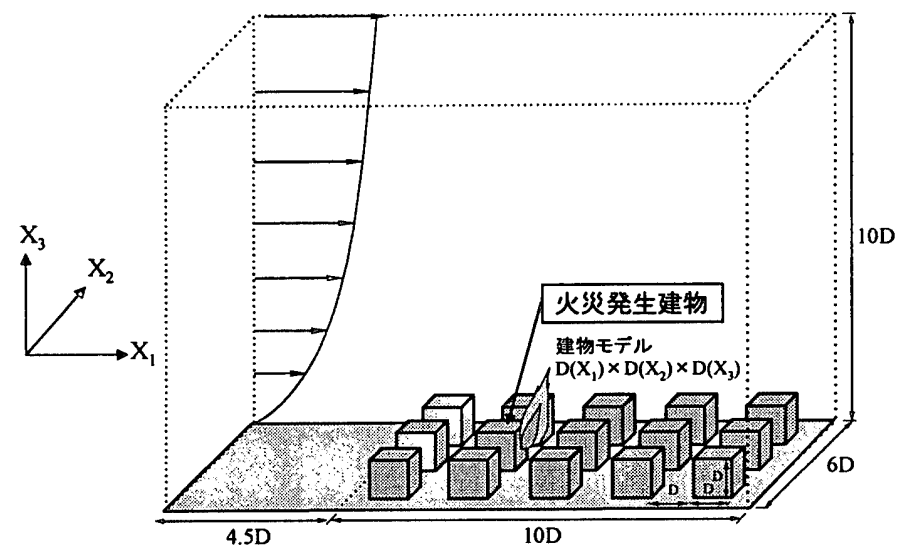

図 1 解析対象

2-1. 解析対象 図 1 に解析対象を示す。解析対象は、 $X_{1}$ 方向に 5つ、 $\mathrm{X}_{2}$ 方向に 3 つの立方体形状の建物モデルを均等に配置した街 区を想定している。解析領域は $14.5 \mathrm{D}\left(\mathrm{X}_{1}\right) \times 6 \mathrm{D}\left(\mathrm{X}_{2}\right) \times 10 \mathrm{D}\left(\mathrm{X}_{3}\right)$ であり、 建物高さ D は本計算では $10 \mathrm{~m}$ とした。建物の幅、奥行きも同様に $10 \mathrm{~m}$ である。解析領域では、左から右へ外部風が流れており、火炎 発生建物は $\mathrm{X}_{1}$ 方向に風上から 2 つ目、 $\mathrm{X}_{2}$ 方向の中心に位置するもの と想定している。

2-2. CFDシミュレーション 本解析では、Boussinesq 近似に基つくく 非氐縮性流体の基礎方程式を用いている住 3)。乱流モデルとしては、 乱流熱フラックスの評価に浮力効果を組み込んだ改良型 k-Eモデル文 11)に、更に建物風上側での乱流エネルギーk の過大生産を抑制する 改良 Launder-Kato モデル文12), 13)を適用し、街区スケールでの流れ場、 温度場等を解析する。これらの乱流モデルの適用に関しては、風洞 実験データとの比較により、その予測精度を確認している⿱亠乂 2-3. 火の粉の拻散シミュレーション 本計算では、火の粉の径が小 さく、その飛散性状が通常の重力沈降する気中浮遊微粒子とみなせ るものと仮定して、火の粉の気中漂度に対する輸送方程式を数值的 に解析してその移流・拡散性状を評価する。火の粉の重力沋降は、火 の粉の気中漂度 $\mathrm{C}$ 個 $/ \mathrm{m}^{3}$ の輸送方程式において、重力沈降((1)式, 文 14)による移流効果を組み込んでいる((2)式, 文 10,注 4)。

尚、火の粉は、地表面および建物上面で沈降により各表面に堆積 して気中より除去されるものとする。地表面および物体上面での濃 度の乱流拡散フラックスは、法線方向勾配 0(乱流扗散による固体表 面沈着無視)と仮定して算出している。

ストークスの重力沈降速度式：

$$
\mathrm{W}=2.46\left[\left(\frac{\rho_{\mathrm{p}}}{\rho}-1\right) \mathrm{rg}\right]^{0.5}
$$

火の粉の気中濃度輸送方程式 :

$$
\frac{\partial \overline{\mathrm{C}}}{\partial \mathrm{t}}+\overline{\mathrm{u}}_{\mathrm{i}} \frac{\partial \overline{\mathrm{C}}}{\partial \mathrm{x}_{\mathrm{i}}}-\mathrm{W} \frac{\partial \overline{\mathrm{C}}}{\partial \mathrm{x}_{3}}=-\frac{\partial}{\partial \mathrm{x}_{\mathrm{i}}} \overline{\mathrm{u}_{\mathrm{i}}^{\prime} \mathrm{C}^{\prime}}+\mathrm{C}_{0}
$$

火の粉の乱流甄度フラックス：

$$
\overline{\left.u_{i}^{\prime}\right)^{\prime}}=-\frac{v_{t}}{\sigma_{c}} \frac{\partial \overline{\mathrm{C}}}{\partial \mathrm{x}_{\mathrm{i}}}
$$

\footnotetext{
C : 火の粉の気中濃度 $\left[\right.$ 個 $\left./ \mathrm{m}^{3}\right]$

$\mathrm{u}_{\mathrm{i}} \quad: \mathrm{i}$ 方向の速度成分 $[\mathrm{m} / \mathrm{s}]$

$\mathrm{W}:$ : 火の粉の重力沈降速度 $[\mathrm{m} / \mathrm{s}]$

$\overline{\mathrm{u}_{i}^{\prime} \mathrm{C}^{\prime}} \quad$ : 火の粉の乱流濃度フラックス $\left[\right.$ 個 $\left./ \mathrm{m}^{2} \cdot \mathrm{s}\right]$

$\mathrm{C}_{0} \quad$ : 単位体積あたりの火の粉の発生量 $\left[\right.$ 個 $\left./ \mathrm{m}^{3} \cdot \mathrm{s}\right]$
}

表 1 計算ケース

\begin{tabular}{|c|c|}
\hline 流入面 & $\begin{array}{l}u_{1}\left(x_{3}\right) / U_{D}=\left(x_{3} / D\right)^{1 / 4}, u_{2}\left(x_{3}\right)=0, u_{3}\left(x_{3}\right)=0, \\
\varepsilon\left(x_{3}\right)=C_{\mu} k\left(x_{3}\right)^{3 / 2} /\left(x_{3}\right), 1\left(x_{3}\right)=4\left(C_{\mu} k\left(x_{3}\right)\right)^{1 / 2} D^{1 / 4} \cdot x_{3}{ }^{3 / 4} / U_{D}, \\
k \text { は風洞実験值文 } 16, \text { 温度は } 300 K, U_{D}=u_{1}(D)\end{array}$ \\
\hline 流出面 & 全て free slip \\
\hline 上空面 & 全て free slip \\
\hline 側面 & $\mathrm{u}_{2}=0$, その他全て free slip \\
\hline $\begin{array}{l}\text { 地表面 } \\
\text { および } \\
\text { 建物表面 }\end{array}$ & 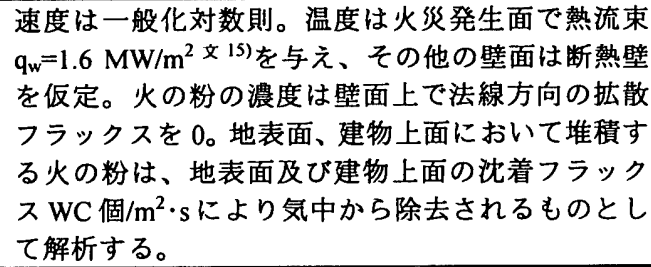 \\
\hline
\end{tabular}

\begin{tabular}{|c||c|c|c|}
\hline & 火炎発生面 & $\begin{array}{c}\text { 接近流速 } \\
\mathrm{U}_{\mathrm{D}}[\mathrm{m} / \mathrm{s}]\end{array}$ & $\begin{array}{c}\text { 重力沋降速度 } \\
\mathrm{W}[\mathrm{m} / \mathrm{s}]\end{array}$ \\
\hline \hline CaseA-1 & 建物上面 & 2 & 0 \\
\hline CaseA-2 & 建物上面 & 2 & 2.85 \\
\hline CaseA-3 & 建物上面 & 2 & 6.37 \\
\hline CaseA-4 & 建物上面 & 5 & 0 \\
\hline CaseA-5 & 建物上面 & 5 & 2.85 \\
\hline CaseA-6 & 建物上面 & 5 & 6.37 \\
\hline \hline CaseB-1 & $\begin{array}{c}\text { 風上側 } \\
\text { 鉛直面 }\end{array}$ & 2 & 2.85 \\
\hline \hline CaseC-1 & $\begin{array}{c}\text { 風下側 } \\
\text { 鉛直面 }\end{array}$ & 2 & 2.85 \\
\hline
\end{tabular}

表 2 境界条件

$\left(\mathrm{k}:\right.$ 乱流エネルギー $\left[\mathrm{m}^{2} / \mathrm{s}^{2}\right], \varepsilon: \mathrm{k}$ の散逸率 $\left[\mathrm{m}^{2} / \mathrm{s}^{3}\right]$.

1 : 長さスケール[m], $\mathrm{C} \mu$ : モデル定数 $(=0.09))$

\section{表 3 計算条件}

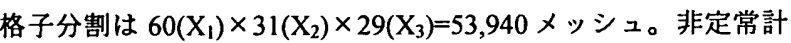
算により定常解を求めている。解法は SIMPLE 法。離散スキー 么は移流項に 1 次風上、その他を 2 次中心差分、時間は全てク ランク-ニコルソン。

$\begin{array}{ll}v_{\mathrm{t}} & : \text { 渦動粘性係数 }\left[\mathrm{m}^{2} / \mathrm{s}\right] \\ \sigma_{\mathrm{c}} & : \text { 乱流シュミット数 }(=1.0) \\ \rho_{\mathrm{p}} & : \text { 少の粉の密度 }\left[\mathrm{kg} / \mathrm{m}^{3}\right] \\ \rho & : \text { 空気の密度 }\left[\mathrm{kg} / \mathrm{m}^{3}\right] \\ \mathrm{r} & : \text { 炎の粉の相当直径 }[\mathrm{m}] \\ \mathrm{g} & : \text { 重力加速度 }\left(=9.8 \mathrm{~m} / \mathrm{s}^{2}\right) \\ (\text { オーバーバーはアンサンフル平均値を示す。) }\end{array}$

2-4. 計算ヶース 火の粉の飛散に最も影響を与える要因として、(1) 風速(本計算では建物高さの接近流速 $U_{D}$ )、(2)火の粉の相当直径(重力 沈降速度 W)、(3)火炎発生位置(火の粉発生位置) 等を変化させて検 討を行う。計算ヶースを表 1 に示す。火の粉の密度をスギの密度 330 $\mathrm{kg} / \mathrm{m}^{3}$ と仮定し、相当直径 $1 \mathrm{~mm}$ および $5 \mathrm{~mm}$ の火の粉の重力沈降速度 を(1)式より求めると表 1 に示すように $2.85 \mathrm{~m} / \mathrm{s} 、 6.37 \mathrm{~m} / \mathrm{s}$ となる。 2-5. 計算条件 火災による発熱は、建物の火级発生面で熱流束 1.6 $\mathrm{MW} / \mathrm{m}^{2}$ 文 15$)$ をえ、火災プリューム中では発熱させていない。

火の粉の発生は建物火炎発生面から生じる火災プリューム上部を 仮定する。今回の検討では、火炎発生建物上面より高さ $8 \mathrm{~m} 、 \mathrm{X}_{2}$ 方 


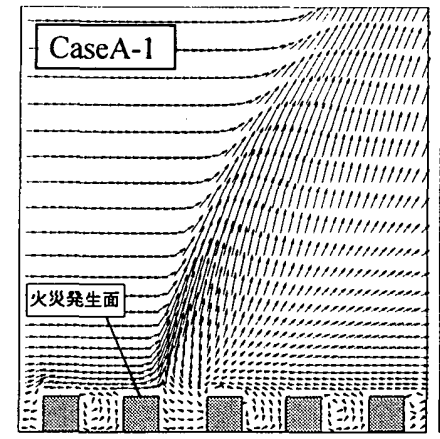

図 2 鉛直面風速ベクトル

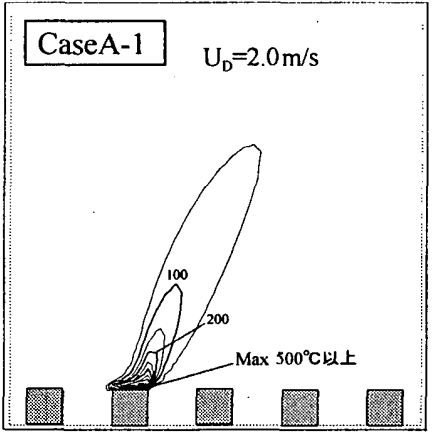

図 3 鉛直面温度分布

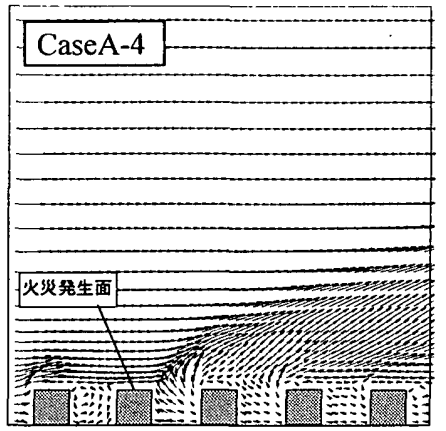

図 4 鉛直面風速ベクトル

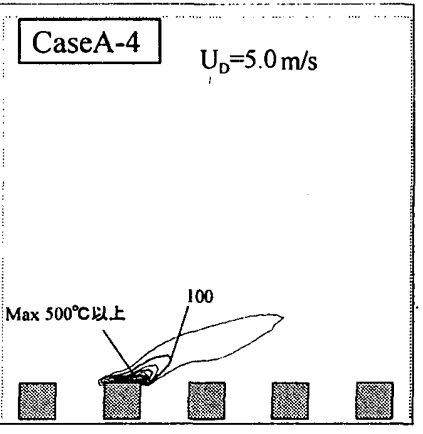

図 5 鉛直面温度分布
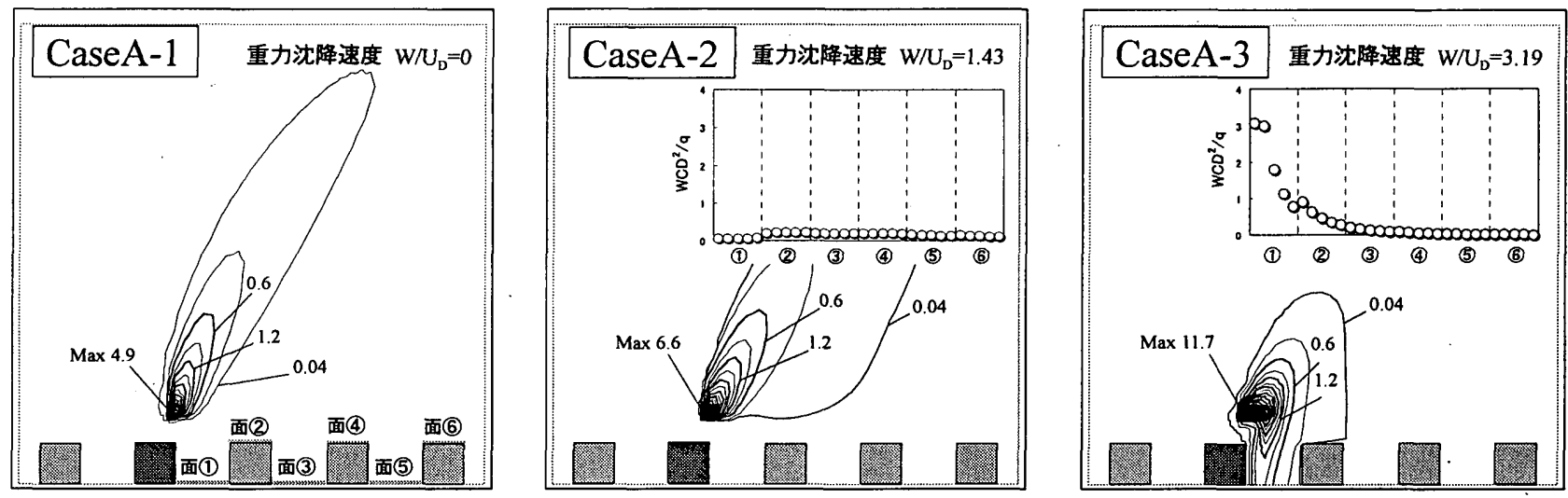

図 6 鉛直面の火の粉の濃度分布 $\left[\mathrm{CU}_{\mathrm{D}} \mathrm{D}^{2} / \mathrm{q}\right]$ 及び沈着フラックス $\left[\mathrm{WCD}^{2} / \mathrm{q}\right]$ （無次元表示, $U_{D}=2 \mathrm{~m} / \mathrm{s}$ ）
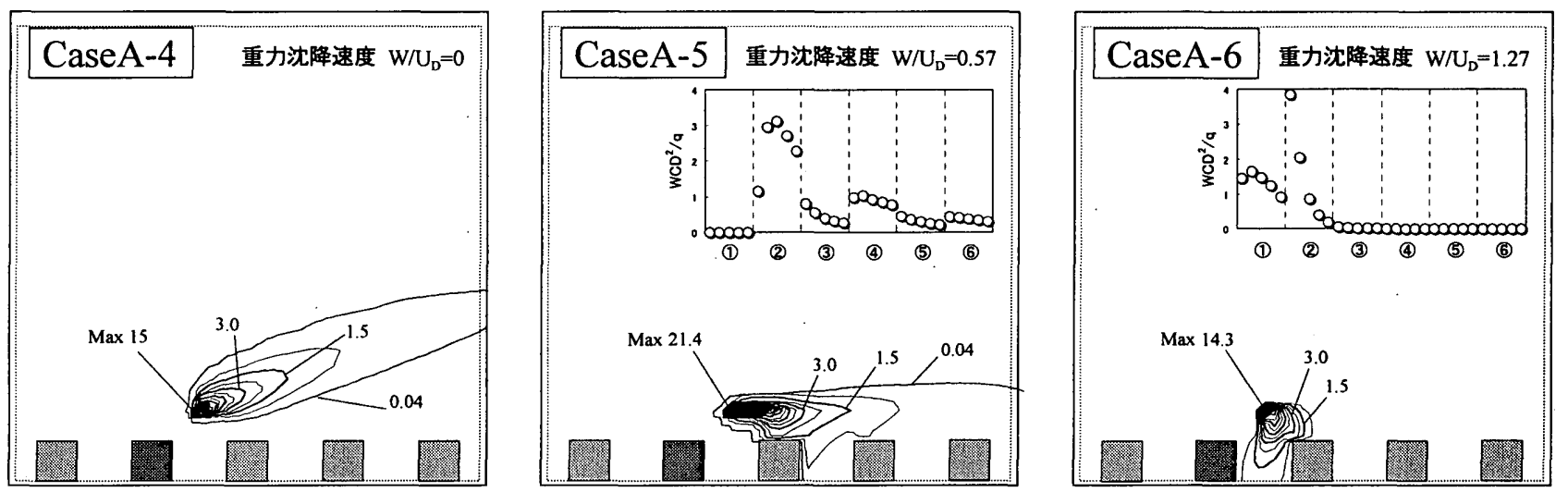

図 7 鉛直面の火の粉の濃度分布 $\left[\mathrm{CU}_{\mathrm{D}} \mathrm{D}^{2} / \mathrm{q}\right]$ 及び沈着フラックス $\left[\mathrm{WCD}^{2} / \mathrm{q}\right]$ （無次元表示, $U_{\mathrm{D}}=5 \mathrm{~m} / \mathrm{s}$ ）

向の中心位置で、最も温度の高いセルとしている。従って、CaseA-1 〜3 と CaseA-4 6 と CaseB-1 と CaseC-1 では、災発生位置が異なっ ており、当然各々流れ場及び温度場が異なるため、火の粉の発生位 置も主流方向に若干異なることになる。解析は定常状態を対象とし ているため、最終的には火の粉の発生量は移流及び拡散により解析 領域から排出される量と建物表面及び地表面から除去される量の和 と等しくなり、質量保存則を満足する。また、火の粉沈着後の再飛 散は考虑されない。

接近流の鉛直方向分布はべキ指数分布を仮定し、高さ Dでの接近 流速 $U_{\mathrm{D}}$ を境界条件として与えている。境界条件およびその他の計 算条件の詳細は表 2、表 3 にそれぞれ示す。

\section{3. 解析結果および考察}

火の粉の濃度に関する以下の結果は、建物高さ $\mathrm{D}$ と接近流速 $\mathrm{U}_{\mathrm{D}}$ および火の粉の発生量 $\mathrm{q}$ 個 $/ \mathrm{s}\left(=\mathrm{C}_{0} \mathrm{~V}=700\right)$ を用い、無次元化して示す。 但し、本計算では単位体積あたりの火の粉の発生量 $\mathrm{C}_{0}$ は 100 個 $/ \mathrm{m}^{3}$.

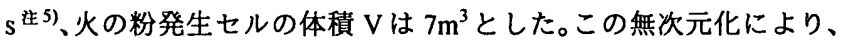
火の粉の代表濃度は $\mathrm{q} / \mathrm{U}_{\mathrm{D}} \mathrm{D}^{2}$ 個 $/ \mathrm{m}^{3}$ となり、算出される濃度はこの代 表値を用いて無次元化される。

3-1. 接近流速の影響 図2，図3にCaseA-1 の、図4，図5 5 に CaseA-4 の鉛直面風速ベクトルおよび温度分布をそれぞれ示す。以下に示す 図の $\mathrm{X}_{1}$ 方向の表示範囲は全て $4.5 \mathrm{D} \leqq \mathrm{X}_{1} \leqq 14.5 \mathrm{D}$ (図 1参照)である。 また、鉛直断面図は全て $\mathrm{X}_{2}=3 \mathrm{D}$ の地点のものである。CaseA-1(図 2) では接近流速 $U_{D}$ が $2 \mathrm{~m} / \mathrm{s}$ と比較的低速であるため、建物上面の発熱 により生じる熱上昇流が卓越し、その影響が解析領域上面(高さ 100 


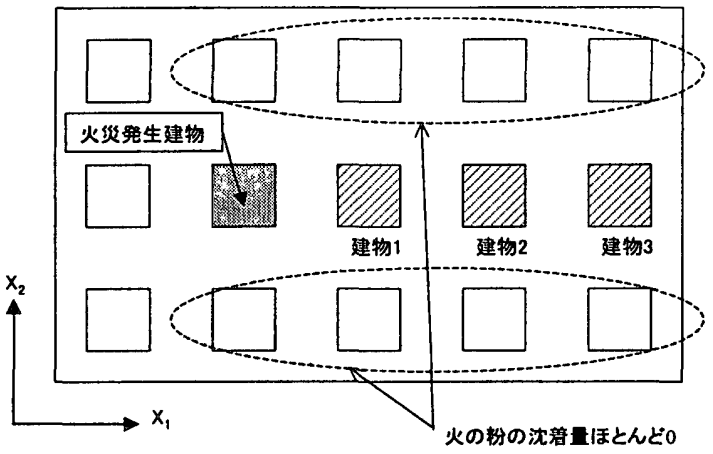

図 8 火災発生建物周㲽の平面図

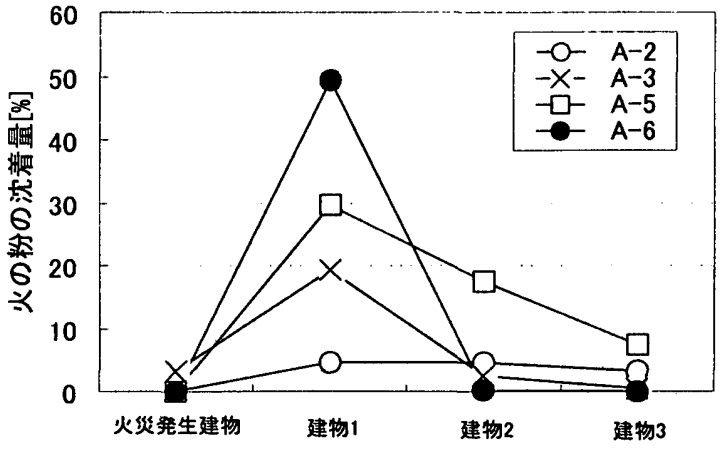

図 9 建物上面の火の粉の沈着量 $\left[\mathrm{WC}_{\mathrm{AVE}} \mathrm{D}^{2} / \mathrm{q} \times 100\right]$

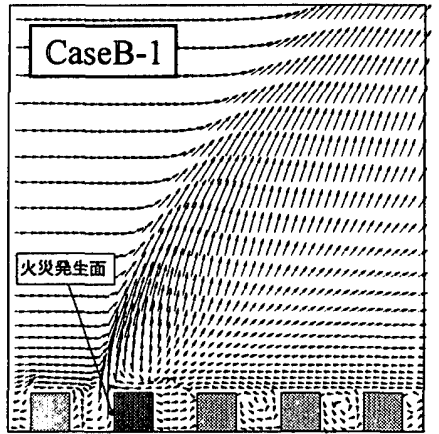

図 10 鉛直面風速ベクトル

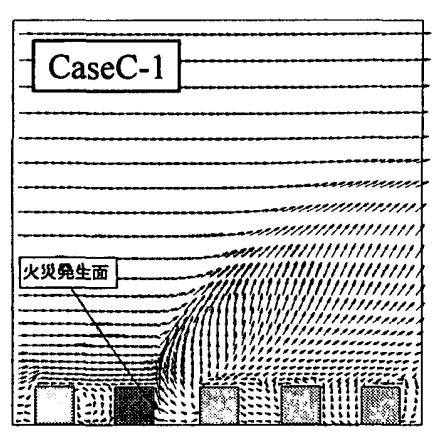

図 13 鉛直面風速ベクトル

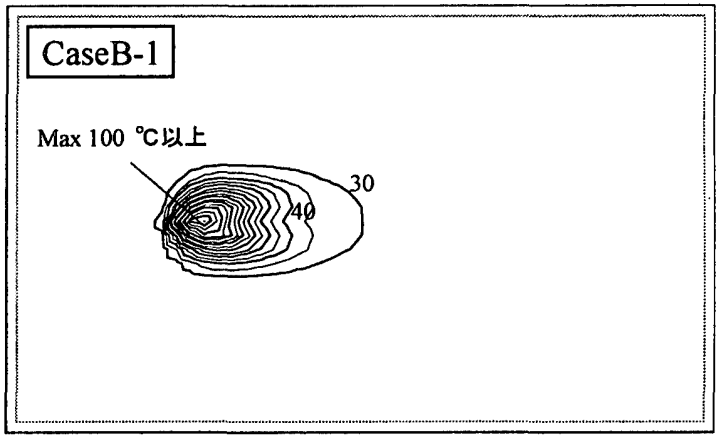

図 11 水平面温度分布（高さ $25 \mathrm{~m}$ )

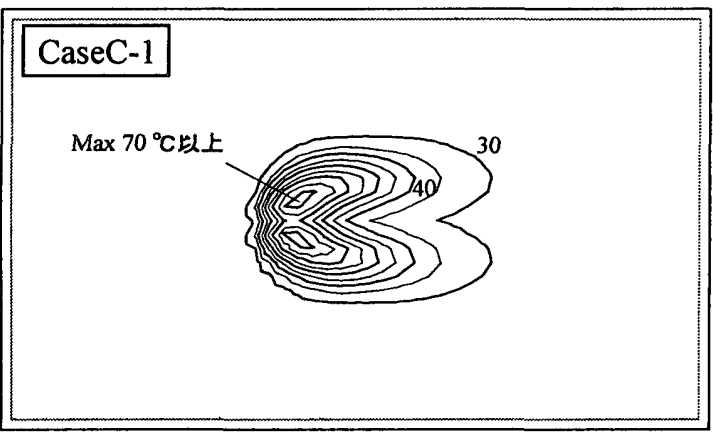

図 14 水平面温度分布（高さ $25 \mathrm{~m}$ ）

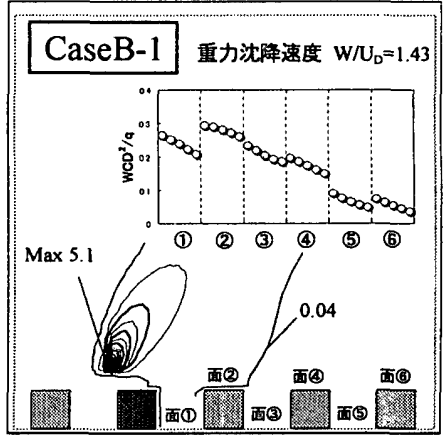

図 12 鉛直面の火の粉の濃度分布 $\left[C U_{D} D^{2} / q\right]$ (無次元表示. $U_{D}=2 \mathrm{~m} / \mathrm{s}$ )

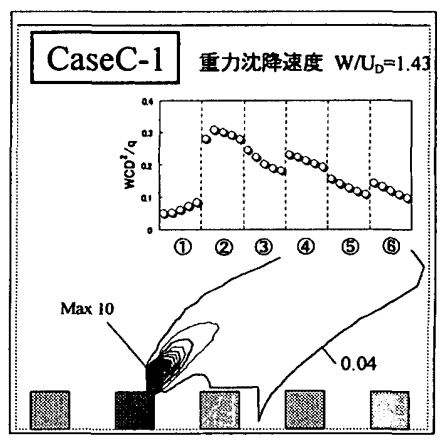

図 15 鉛直面の火の粉の濃度分布 $\left[C U_{D} D^{2} / q\right]$ (無次元表示, $U_{D}=2 \mathrm{~m} / \mathrm{s}$ ) m)まで達している。これと比較して CaseA-4(図 4)では接近流速が 5 $\mathrm{m} / \mathrm{s}$ と強風であるため、接近流速が卓越し、熱上昇流は抑制されて いる。温度分布に関して、CaseA-1(図 3)では高温域が上空まで形成 され、高温域の風下側への傾きは小さい。一方、CaseA-4(図 5)では、 高温域が風下側へ大きく傾き、風下に陊接する建物近傍まで及んで おり、火炎の傾きによる輻射熱や火の粉飛散による風下側に䇟接す る建物への延焼危険性が高くなる。

図 6. 図 7 にCaseA-1〜3 および CaseA-4〜6 の鉛直面の火の粉の無

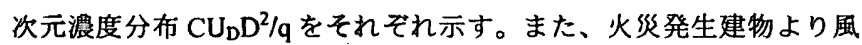
下側の地表面および建物上面(図 6 左図中に示す面(1) 面(6)に沈降 する火の粉の無次元沈着フラックス $\mathrm{WCD}^{2} / \mathrm{q}$ 永6) も図中に示す。強風 時においては(図 7)、温度分布と同様に高濃度領域の風下側への傾き か゚大きく、風下側の火の粉の沈着フラックスも大きくなり、そのピ 一ク值も風下側へ移行する。従って、強風時においては風下側に隣
接する建物への延焼危険性が高くなると考えられる。

図 8 に火炎発生建物周辺の平面図を、図 9 に CaseA-2, A-3 及び CaseA-5, A-6 の建物上面の火の粉の沈着量 $\mathrm{WC}_{\mathrm{AVE}} \mathrm{D}^{2} / \mathrm{q} \times 100$ 生7)\%を 示す。ここで、 $\mathrm{C}_{\mathrm{AVE}}$ は各建物上面第 1 セルにおける火の粉の濃度 $\mathrm{C}$ の平均値を示す。また、図 9 の横軸の項目名は図 8 に対応する。図 8 に示すように今回の計算条件下では、 $\mathrm{X}_{2}$ 方向に 1 列目及び 3 列目 の建物上面への火の粉の飛散は殆どなく、沈着量としては $\mathrm{X}_{2}$ 方向に 2 列目の建物上面への沈着量に対して最大で $10^{-4}$ 程度のオーダーで あった。また図 9に示すように接近流速が速いほど風下側の建物上 面への沈着量は多くなる結果となった(CaseA-2, A-3 と CaseA-5, A-6 の比較)。

3-2. 火の粉の重力沈降速度(相当直径)の影響 重力沈降速度 $\mathrm{W} / \mathrm{U}_{\mathrm{D}}=0$ の場合(図 6,7 の左図)、火の粉は熱上昇流及び接近流によりパッシフ に輸送され、建物及び地表面まで達しない。 


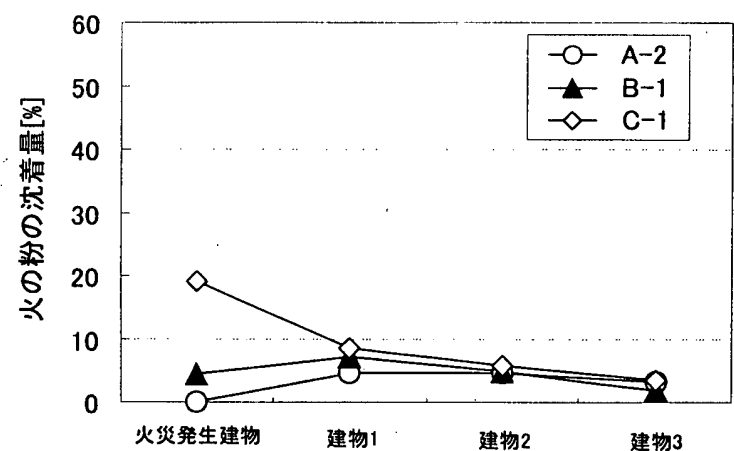

図 16 建物上面の火の粉の沈着量 $\left[\mathrm{WC}_{\mathrm{AVE}} \mathrm{D}^{2} / \mathrm{q} \times 100\right]$

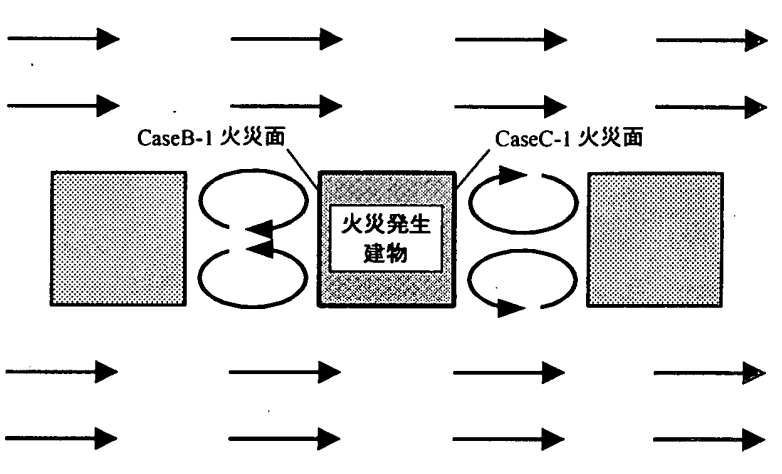

図 17 火炎発生建物近傍の水平面気流パターン
火の粉の相当直径が $1 \mathrm{~mm}$ の場合(図 6,7 の中図)、火の粉は風下傊 の建物上面に沈着するようになり、風下側ほど沈着フラックスの值 は小さくなる。火炎発生建物より風下側 1 つ目の建物上面(面(2)に は、単位時間あたりの火の粉発生量の $5 \%$ (CaseA-2)、30\%(CaseA-5) がそれぞれ沈着している(図 9参照)。特に強風時の場合(図 7 の中図)、 熱上昇流の発達が抑制されるため、重力沈降の効果が顕著に現れ、 火炎発生建物から風下側 2 つ目の建物(面(4))まで約 $20 \sim 30 \%$ (CaseA-5)という高い割合で火の粉が到達しており(図 9 参照)、これ らの建物では延焼危険性が高いと考えられる。

火の粉の相当直径が $5 \mathrm{~mm}$ の場合(図 6,7 の右図)、重力沈降が支配 的となり、火の粉は殁ど上空には舞い上がらず、その大部分が火炎 発生建物近傍の地表面(面(1)および風下側 1 つ目の建物上面(面(2) に堆積している。図9に示すように低風速の場合(CaseA-3)、火の粉

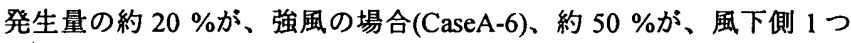
目の建物上面(面(2)に堆積している。ただし、両ヶースのこの沈着 量の差は、CaseA-3(図 6 の右図)と CaseA-6(図 7 の右図)を比較すると 接近流速の差よりも、火の粉の発生位置の微妙な差(CaseA-6 の方が 流れ場の違いにより発生位置が若干風下側に位置している)が最も 影響しているものと考えられる。また、両ケースとも建物 2 以降は 火の粉が殆ど堆積していない。

図 9 に示すように全体的な傾向としては、重力沈降速度が速いほ ど(火の粉の相当直径が大きいほど)、風下側の建物上面への火の粉 の沈着量が多くなる(CaseA-2, A-5 と CaseA-3, A-6 の比較)。

3-3. 火災発生位置の影響 CaseB-1 および CaseC-1 の鉛直面風速べク トル、水平面温度分布、鉛直面の火の粉の無次元濃度分布を図 10 から図 15 にそれぞれ示す。また図 16にCaseA-2、CaseB-1、CaseC-1 の建物上面の火の粉の沈着量 $\mathrm{WC}_{\mathrm{AVE}} \mathrm{D}^{2} / \mathrm{q} \times 100 \%$ を示す。

CaseB-1(図 10)の場合、建物上面から発熱する CaseA-1(図 2)と同様 に火災による熱上昇流が解析領域上面(高さ $100 \mathrm{~m}$ )まで及んでいる が、風下面から発熱する $\mathrm{CaseC}-1$ (図 13)の場合、高さ $60 \mathrm{~m}$ 程度であ る。また、水平面の温度分布(高さ $25 \mathrm{~m}$ )に関しても、Case C-1(図 14) の場合、CaseB-1(図 11)と比較すると高温域の最高温度が低く、また 高温域が風下側に分岐して形成されている。このような差異が生じ る原因は明らかでないが、図17 に示す建物間の水平方向の循環流の 影響があるものと考えられる。すなわち、風上側鉛直面に火炎発生 面がある CaseB-1 では、火炎発生面前方に生じる循環流が発熱面で
収束流を形成し、水平方向の熱执散を抑制するように働き、一方、 風下側鉛直面に火災発生面がある CaseC-1 の場合は循㻴流が発熱面 で発散流を形成し、水平方向の熱拡散を促進する。この効果により CaseC-1 では熱上昇流の上昇速度が低下し、図 13 に示されるように 接近流の卓越した流れ場が形成されたものと考えられる。

火の粉の飛散に関しては、流れ場の影響を受け、CaseB-1(図 12) では上空への飛散量が多いため風下側の建物上面への㶩着フラック スは、CaseC-1(図 15)と比較して若干小さい。図16に示すように建 物上面への沈着量も数\%ではあるが、CaseB-1 の方が少ない。 CaseA-2(図 6 の中図, 図 9)においては、建物上面への沈着量は、更に 少ない。従って、火災発生面が建物の風上側鉛直面(CaseB-1)および 建物上面(CaseA-2)にある場合には、熱上昇流が発達し、直上への火 の粉飛散を助長することになり、風下側に瀿接する建物上面での沈 着フラックスが小さくなる。また、火炎発生面の位置が、熱上昇流 等の流れ場の性状に大きく影響を与え、最終的には火の粉飛散に影 響を与える重要な要因になると考えられる。

\section{4. 結論}

都市火災の伝搬要因の一つである火の粉飛散による飛び火現象の 物理モデルを作成し、建物周辺気流の CFD 解析と連成させて直径 $1 \mathrm{~mm}$ から $5 \mathrm{~mm}$ 程度の火の粉飛散の数値解析を行い、以下の知見を 得た。

1) 接近流速が比較的低速の場合、浮力が卓越し、熱上昇流が上空 100 $\mathrm{m}$ 以上まで形成されるが、強風の場合、接近流が卓越し、熱上昇 流が抑制される。

2) 強風時においては、火の粉の高濃度領域が風下側へ形成され、風 下側に隣接する建物上面への火の粉の沈着フラックス及び沈着量 ともに多くなる。

3) 重力沈降速度が速いほど(火の粉の相当直径が大きいほど)、火災 発生建物の風下側に隣接する建物上面への火の粉の沈着量が多く なり、結果的に更に風下側に位置する建物上面への沈着量は少な くなる。

4) 建物の風上側鉛直面に火災発生面がある場合、火災発生面前方に 生じる循環流が収束流を形成し、水平方向の熱抾散を抑制する。 一方、風下側鉛直面に火炎発生面がある場合は循環流が発散流を 形成し、水平方向の熱拡散を促進し、結果的に接近流速が同じ他 
のケースと比較して熱上昇流が抑制される。

5) 火災発生面が建物の上面および風上側にある場合には、火災によ る熱上昇流が発達し、上空への火の粉飛散を助長することになり、 結果的に風下側に隣接する建物上面での火の粉の沈着量は少なく なる。

本報で示した火の粉飛散のシミュレーション結果と実現象との対 忍に関しては、今後検が必要であることは言を待たない。但し、今 回の解析で検討対象とした直径 $1 \mathrm{~mm}$ から $5 \mathrm{~mm}$ の火の粉の飛散モデ ルは、浮避微粒子の移流・扗散現象の解析において、既に十分検討 が行われている文 10)。今回検討対象とした径以外の火の粉がどの程 度発生するか 等 発生と飛散現象のモデリング、火の粉の発生位置、 火源のモデリング、火级現象の非定常性 等に関して、今後更なる検 討が必要と考えられる。

注

[1]飛び火現象は、(1)火源から発生した火の粉が飛散する現象と(2)火の粉が 飛散した後に離れた場所に沈着し火災が起きるという現象の双方を意味 する。

[2] ここで、飛び現象の物理モデルとは、火源から発生した火の粉の飛散 をモデル化したものであり、火の粉が飛散した後に離れた場所に沈着し、 火災が起きるという現象を取り扱うものではない。ただし、本モデルは 火の粉の飛散から矿着までをモデル化しており、火の粉の沈着量に基つ いて簡易的に火災発生の危険性を予娜することは可能である。

[3] 火级時のように温度差の大きい流れ場の解析において Boussinesq 近似に 基つく基礎方程式を用いることは、本来不適切であると考えられる。し かし、実祭に近似俱差生じるのは、火源近傍の温度勾配の大きい非常に 限られた領域であるため、解析領域全体への Boussinesq 近似の与える影 掣は小さいと考えられる。この点の検討は今後の検討課題としたい。

[4]重力訧降を考虑する火の粉の物理モデルは、火の粉の終末沈降速度(火の 粉の粒子に加わる外力が重力の場合のみ、その初速度のいかんにかかわ らず重力と空気から受ける抵抗力が釣り合ったときの平均速度)を火の 粉の漫度輸送方程式中で考慮するモデルであり、以下のような問題点が 考えられる。(1)水平方向の抵抗力が考慮されていない(水平方向には流れ に治って輸送されるというパッシブスカラーを仮定)。(2)火粉の初速度 の影頯が考魔されていない(火源近傍から発生した火の粉が既に終末速 度に達しているものと仮定)。ただし、(1および(2)の問題点は火の粉の相 当直径が小さい場合すなわち終末沈降速度が流速と比較して十分小さい 場合、例えは森林火炎における火の粉飛散等の解析には、罗当な解法て ある。また、火の粉の一つ一つの挙動を解析するモデルと比較すると、 火の粉を濃度として取り报うため、汎用的な解法であるとも考えられる。

[5] C C の值は一般に外部風速により影稫を受けると考えられるが、本研究て は火の粉飛散に関する定性的な検討に主眼を直いているため、ここでは 全ての計算ヶースにおいて一定とした。

[6] 幅 $\mathrm{D} \mathrm{m}$ の矩形水平面に落下する火の粉の無次元㶩着フラックス $\mathrm{WCD}^{2} / \mathrm{q}$ は、単位時間あたりの火の粉発生量 q 個/s の内、フラックスを定義する 矩形水平面 $\mathrm{D}^{2} \mathrm{~m}^{2}$ に耽降する火の粉の割合を示す。

[7] 建物上面の火の粉の沈着量 $\mathrm{WC}_{\mathrm{AVE}} \mathrm{D}^{2} / \mathrm{q} \times 100 \%$ \% 、建物上面の火の粉の

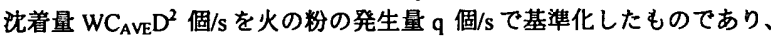
単位時間あたりの火の粉発生量の内、各建物上面に耽着する火の粉の割 合を示す。

参考文献

[1]系井川栄一，塚越巧：飛火を考感した市街地火災の確率的延焼モデル，第 23 回日本都市計画学会学術研究論文集, pp.469-474, 1988 年.

[2] 系井川栄一，塚越巧：市街地火炎の延焼速度予測に関する研究，第 24 回日 本都市計画学会学術研究論文集, pp.79-84, 1988 年.

[3]矢野公一, 松井武史, 高井広行, 坊池道昭, 上村雄二 : 大規模震災火災の延 雄シミュレーションに関する研究, 土木学会土木計画学研究・講演集, No.19(2), pp.39-42,1996 年

[4]保野煡治郎, 難波義郎, 西谷忠彦：地震時市街地火炎の延焼速度式と予漱 に関する基的研究，日本建築学会計画系論文集，No.501,pp.9-15, 1997 年
11 月

[5]難波義郎, 保野揵治郎：地震時市街地火災の延焼速度に関する基磷的研究， 日本建築学会計画系論文集, No.520, pp. 1-7, 1999 年 6 月.

16!佐賀武司: 強風下における帯状熱源からの熱気流の風下温度分布，强風下 の市街地大火における火炎気流の温度分布に関する基礎的研究, 日本建 築学会構造系論文報告集, No.408, pp.99-110,1990年 2 月.

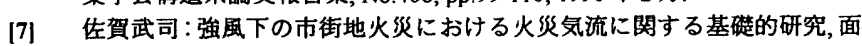
熟源の風下温度分布式に関する理論的考察, 日本火災学会論文集, Vol.46, No.1·2, pp.1-11, 1997 年

[8]加藤信介, 村上周三, 石田義洋, 大平昇：震災ビル火炎時の周辺熱気流性状 のCDF 解析,第 1 回都市直下地震災害総合シンポジウム,pp.271-274, 1996 年.

[9]白石靖幸, 村上周三, 加藤信介, 大岡龍三, 金サンジン, 菻山正和 : 数值気候 モデルを利用した神戸市大規模火级時の広域熱気流、払散性状の解析, 第 2 回都市直下地䟴災害総合シンポジウム, pp.411-414, 1997 年.

[10]村上周三, 加藤信介，永野紳一郎：移流の卓越する室内気流における沈降 を伴う浮遊微粒子の抾散, 第 2 報一数值シミュレーションと実大実験の比 較, 空気調和・衛生工学会諭文集, No.40, pp.37-45, 1989 年.

[11]野口康仁, 村上周三, 持田灯, 富永禎秀: 都市温熱環境の数值シミュレーシ ョン(その 3), k-єモデルの乱流熱フラックスの評価への浮力効果の組み込 み, 日本建築学会大会学術講演梗概集(環境), pp.65-66, 1994 年.

[12] B. E. Launder, M. Kato : Modeling Flow-Induced Oscillations in Turbulent Flow around A Square Cylinder, ASME Fluid Eng. Conference, pp.20-24, 1993.

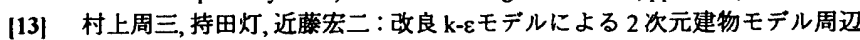
気流の数值計算，生産研究(東京大学生産技術研究所所報), Vol.47, No.2, pp.29-33, 1995 年.

[14]高橋幹二, 改著基碳エアロソル工学(第一版), 養㹂堂, 1982 年

[15] 横井鎮男(建築研究所), 建築研究報告, No34, 1960 年.

[16] 村上周三, 持田灯, 林吉彦: $\mathrm{k}-\varepsilon$ モデルにおける建物風上の $\mathrm{k}$ の過大評価 とモデルの改良, 第 10 回 風工学シンポジゥム論文報告集, pp.199-204, 1988 年.

（2000年11月 8 日原稿受理，2001年 3 月 22 日採用決定） 